\title{
Uninformed Voters for Sale: Electoral Competition, Information and Interest Groups in the US
}

\author{
Tim Wegenast*
}

\section{INTRODUCTION}

Interest groups are often seen as a major factor explaining public policy outcomes in the United States. While political scientists have taken contradictory stances over the value of interest groups as a vehicle of popular representation, it seems indisputable that interest groups' influence has grown steadily. Particularly during the early seventies, an expansion occurred in both the number and variety of groups (see Gray and Lowery, 2001 or Berry, 1997). This development is reflected in political science research and the interest group approach has become a prominent explanation for various outcomes. ${ }^{1}$

When posing the question of what determines the amount of power interest groups have within the policy making process, the literature has mainly relied on internal characteristics of organisations through case studies (see Baumgartner and Leech, 1998, pp. 177-80). Several empirical analyses have addressed how internal factors such as group size, organisational structure or financial resources drive mobilisation or affect the different channels of influence. So far, however, little attention has been paid to external sociopolitical forces as determinants of groups' influence-seeking behaviour.

The present paper can be seen as a contribution to correct this oversight within the interest group literature. The central question is why does the number of campaign contributions and lobby registrations as well as the perceived influence of interest groups vary so immensely across the US states.

* Post-doctoral fellow, University of Konstanz, and research fellow, German Institute of Global and Area Studies. Correspondence address: Department of Politics and Management, University of Konstanz, Box D 86, 78457 Konstanz, Germany, tim.wegenast@uni-konstanz.de. I acknowledge the very helpful comments of the participants of the $64^{\text {th }}$ MPSA Annual National Conference, Chicago, 2006; the $8^{\text {th }}$ AECPA Annual Congress, Valencia, 2007 as well as Gøsta Esping-Andersen, Jacint Jordana Casajuana, Reiner Eichenberger, Sunnee Billingsley and two anonymous reviewers. I also thank Carles Boix, David Lowery and Mark Smith for making their data available.

1. Ansolabehere et al. (2003) surveyed nearly 40 papers in economics and political science analysing the relationship between PAC contributions and congressional voting. For a meta-analysis of campaigns' impact on roll call voting, see Roscoe and Jenkins (2005). 
Drawing on previous formal models such as the one developed in Grossman and Helpman $(1994,1996)$, this work concentrates on voters' information level and, to a minor extent, electoral competition as crucial determinants of whether office-holders choose to satisfy median voters' interest or rather strengthen their relationships with special members of society, e.g. by demanding more lobbying activities such as campaign contributions in exchange for narrowlytargeted policies.

The main argument postulates that special interest groups are increasingly valued within parties' utility function when there is a higher share of uninformed citizens among the electorate. Since uninformed individuals can hardly evaluate past performances, assess party programs or connect a certain policy proposition to their own welfare, candidates use electoral contributions from interest groups to gain the political support of these 'impressionable' voters. Better informed citizen, in contrast, are more likely to punish 'bad' politicians at the polls, increasing politicians' incentives of enhancing voter's welfare as opposed to serving special interests.

In addition, it will be tested whether increasing electoral competition reduces interest groups' readiness to make donations to the opposing parties. Facing higher electoral uncertainty, interest groups are forced to split their contributions, being less effective in 'buying' legislation by means of campaign money. On the contrary, low inter-party competition leads groups to concentrate on the 'winning' party, being able to demand more special favours afterwards. This hypothesis will be contrasted with empirical findings suggesting that electoral competition is associated with enhanced interest groups' activity.

Finally, the combined effect of electors' information and political competition on the influence of special interest groups is analysed. Politicians are expected to further the general public welfare instead of granting private rents to narrow interests whenever electoral competition and voters' information is high. Under such circumstances, serving the median voter's interest seems to be the most efficient instrument for securing political power. This is because political parties fear losing too many votes from the informed electorate in disputed electoral races if they were to deviate from the median voter's preferences and satisfy special interests.

All three outlined propositions will be tested by employing alternative measures of interest groups' activity: total campaign contributions, number of lobbying registrations and advocacy groups' perceived power. The paper proceeds in the following way: The next two sections briefly review the determinants of interest groups' strength that are commonly found in the literature, outlining the existent empirical and formal work that examine the relationship among interest groups' activity, voters' level of information and electoral competition. Section four outlines the hypotheses as well as the proposed causal mechanisms to be tested. Next, the research design and data 
used in the empirical analyses are described and the main results are reported. The final section concludes by summarising the most important findings and identifying some open questions that might be answered in further research.

\section{DETERMINANTS OF INTEREST GROUPS' POWER: A BRIEF LITERATURE REVIEW}

As previously stated, the interest group approach has proven to be highly influential within different fields of political science. Scholars such as David Truman (1951) or Robert Dahl (1961) have already addressed the fundamental question of 'who wields power and influence and whose views are represented in a democracy' (see Baumgartner and Leech, 1998, p. 44). A look at the composition of the interest group system in the US reveals that business and trade associations dominate numerically and that truly 'public' interest groups are relatively rare (see Grier et al., 1994; Lowery and Gray, 2004). ${ }^{2}$

Interest-group theory posits that whenever the benefits of lobbying exceed its costs, lobbying registrations and contributions should increase. So what are the forces driving groups to organise for collective action in a cost-efficient way and that are leading them to expect high potential benefits? Referring to internal factors, Olson (1965) argues that the organisational and running costs of an interest group are a positive function of community size. Following Olson, much of the subsequent work used internal factors to explain interest groups' development (see Salisbury, 1969; Moe, 1980; Rothenberg, 1988). In line with this literature, Stigler (1976) claims that population density affects the costs of organising coalitions either to support or to oppose specific legislation (see also Heinz et al., 1993).

Besides population density, more recent work found that other environmental variables influence mobilisation costs and the potential benefits of interest groups' activity. Kennelly and Murrell (1991) show that industry characteristics such as the industry's concentration ratio (as a proxy for freeriding effects) are positively related to interest group formation. Another external force that seems to drive interest groups' behaviour is the level of economic development. In a recent empirical analysis, Bischoff (2003) finds support for the hypothesis that an increase in the number of interest groups over time is concomitant with economic development.

To a lesser degree, scholars have examined the demand side for interest groups' contributions. Research on the influence of the external political

2. A ranking of the forty most influential interest groups in the United States by Thomas and Hrebenar (2004, p. 119) shows that no public interest or citizen group ranked in the top twenty. The highest rankings are dominated by businesses and the professions. 
environment on transactions between policy-makers and groups is still underdeveloped. Some work within the public choice framework concentrated on the institutional powers of political agents as facilitators of transfers. Formal models like the one in Grier and Munger (1991), for example, show that powerful policy-makers are more valuable for interest groups, since they can deliver each unit of 'effective access' at a lower cost. Examining the demandcreating actions of government, Leech et al. (2005, p. 19) conclude that 'groups become active in Washington, D.C., in large part because of pre-existing levels of government activity in the issue-areas that concern them'.

Apart from the mainly institutional factors mentioned above, almost no work exists on possible determinants shaping the demand for interest groups' contributions. With few exceptions, the literature tells us very little about whether electoral competition and voters' information are crucial variables in explaining the unequal degrees of influence that interest groups have in each of the 50 states. Thus, direct evidence testifying to the relationship between electoral competition and interest groups' influence is scarce.

Analysing a panel of campaign contributions and campaign spending in gubernatorial elections from 1976 to 2000, Ansolabehere et al. (2003) conclude that electoral competition increases campaign spending in state gubernatorial races. Lowery and Gray (1997) find that higher levels of party competition are associated with more interest group activity as measured by the total number of organization registered to lobby in 1990.

Concerning voters' level of information, it is commonly asserted that elections increase collective welfare only to the extent that citizen are knowledgeable about politics (Gastil, 2000; Tóka, 2008). In general, it is believed that poor information among voters produces an elitist or class bias in public policy (see Ferguson, 1983). Also, there is evidence that an informed citizenry may spur governments' accountability, effectively diminishing the incidence of corruption among office holders (Adserà et al., 2003; Deininger and Mpuga, 2005). Based on the assumption that better informed voters receive favourable politics, Strömberg (2004a) claims that it is costly for politicians to ignore voters who have broad access to political information. Employing empirical data, the author shows that US counties with many radio listeners received more funds from the New Deal relief program in the 1930s. Using 16 Indian states as unit of analysis, Besley and Burgess (2002) find that governments' provision of public food and calamity relief expenditure is greater in states with high newspaper circulation.

Despite of the works reviewed above, empirical evidence linking voters' information levels and the power of interest groups is - to the best of my knowledge - nonexistent. The present article is novel in empirically testing the link between citizen informedness and special interest groups by employing three alternative measures of advocacy groups' activities. In addition, it explores potential interaction effects between voters' level of information, 
electoral competition and interest groups' influence by relying on the intuition of formal economic models briefly reviewed below.

\section{ELECTORAL COMPETITION; VOTERS' INFORMATION AND POLICY OUTCOMES: THE FORMAL POLITICAL ECONOMY LITERATURE}

The models presented in this section mostly focus on the strategic interaction between interest groups and policymakers, assuming that groups may directly affect the policymaker's utility. Candidates in these models value electoral contributions since they can be used to increase their political power base (e.g. by enhancing the probability of re-election). In the seminal work of Gene Grossman and Elhanan Helpman $(1994 ; 1996)$, the cost of attracting contributions, conditioned by voters' level of information, may be a loss of votes due to a shift of policies toward favouring special interest groups. Individual interest group's motivation in making contributions is the prospect of 'buying' policies or enhancing the electoral outcome probabilities of their favourite candidate. The authors consider the incumbent politicians' objective as being the maximisation of a 'weighted sum of total political contributions and aggregate social welfare' (Grossman and Helpman, 1994, p. 386). Incumbent politicians will choose to implement a relatively inefficient policy (that is, a policy deviating from the interest of the median voter) whenever the benefit gained from special interest groups outweighs the potential electoral loss.

Grossman and Helpman (1996, p. 266) consider a setting of two parties and one interest group. The two parties compete for legislative seats and announce their respective policy platforms through cost-intensive campaigning. By enacting policies that satisfy the general public, a party can expect votes from the portion of the electorate that is well-informed about the party's position on the issues. At the same time, parties may cater to contributions from special interest groups by choosing to implement narrowly-targeted policies. These cash or in-kind contributions may be used to influence the votes of less-informed (or 'impressionable') voters. Uninformed voters can be easily swayed by the message of the electoral campaign, whereas informed voters analyse both parties' positions, voting for whichever party offers a higher utility. According to the authors, parties resolve this trade-off "with the aim of maximizing their representation in the legislature' (Grossman and Helpman 1996, p. 266). ${ }^{3}$

Building on the Grossman and Helpman framework, Strömberg (2001), includes mass media in order to endogenize who is informed and who is not.

3. For other models that are very close to Grossman and Helpman's, see Hillman and Ursprung (1988), Austen-Smith (1987) or Baron (1994) 
The importance of mass media is, among other things, to inform 'backwardlooking voters about actions taken by the politicians which are not directly observable, such as budget deficits, or about who is responsible for cuts or increases in programs they care about' (Ibid, p. 653). The model suggests that enhanced political knowledge - induced by mass media expansion - may spur the political influence of large, dispersed groups at the expenses of small, wellorganized special interest groups, thereby altering the trade-off in political competition (see also Strömberg, 2004b).

A more recent group of models assume that voters update their beliefs rationally and that campaign advertising is directly informative. In these models, candidates use campaign money in order to convey information about their policy positions, ideologies or qualifications to voters, thus allowing for more informed choices. Coate (2004, p. 628), for example, argues that 'the potential social benefit of contributions lies in giving qualified candidates an electoral advantage over unqualified opponents' (see also Ashworth, 2006). ${ }^{4}$ Other authors assume that contributions serve as nondirectly informative advertising. According to them, the total amount of collected campaign money is not used to provide a direct message. Instead, it signals candidates' valence to voters (Potters et al., 1997; Prat, 2002).

Based on some rationales of the models outlined above, the next section explicitly formulates hypotheses on how the interaction between different levels of information and electoral competition affects the total amount of campaign contributions, the number of lobbying registrations and the overall power of special interest groups.

\section{IMPLICATIONS FOR GROUPS' INFLUENCE WITHIN POLITICAL SYSTEMS}

In general, the framework put forward by Grossman and Helpman suggests that low levels of electoral competition increase campaign contributions as well as the total number and political influence of special interest groups. This can be explained by the model's prediction that the party more likely to win a majority of seats in the legislature and in a position to set policy will attract more attention from special interests groups. Consequently, this party will tend to adopt a platform of pliable policy positions closer to interest groups' concerns. With the obtained campaign contributions, the party tries to win the

4. Parallel to these models, there are interesting works showing how candidates' efforts to provide information to voters may be driven by mass media attributes. As argued by Oberholzer-Gee and Waldfogel (2006), for example, the provision of media content is characterized by economies of scale and, consequently, small groups are offered fewer media products to their liking. This situation, according to the authors, hampers candidates' attempts to reach and mobilize these citizens, as "[l]arger groups are more likely to be the targets of political campaigns" (Ibid, p. 74). 
votes of undecided electors. The second party may also cater to special interest groups, but its platform is much closer to the median voter. The authors claim that the majority party may use its popularity in "campaign war chests, with detrimental effects on the welfare of the average voter' (Grossman and Helpman, 1996, p. 283). ${ }^{5}$

Thus, the first hypothesis to be tested empirically in this paper is that lower levels of electoral competition produce more active and politically influent interest groups. Note, however, that there are also good reasons to suspect that advocacy groups' power in fact increases when electoral races are more competitive. Under high electoral competition, interest groups' partisan choices may lead them to donate more in order to enhance the winning prospects of their favourite candidate. ${ }^{6}$ The empirical tests in the next section are expected to bring further clarification to this question.

As outlined, the way incumbent parties solve the trade-off between catering to special interests and providing broad and efficient public policies to the electorate depends largely on the level of voters' information. With an increase in the share of informed voters within the population, policy-makers are expected to become more responsive to the interests of this constituency. Vice versa, the aggregate interests of special groups receive a weight that increases with the number of uninformed and impressionable citizens. Voters are often unable to attribute a specific policy contribution to the respective party or connect a given policy to their own welfare. This lack of information makes it difficult for them to assign credit or blame (see Downs, 1957). Consequently, they can be swayed by political advertisements and politicians have heightened incentives to cater to special interests rather than satisfying median voter's bliss point. ${ }^{7}$ Thus, other things equal, incumbent officers should value special interests more whenever electoral competition is low or the share of uninformed voters within the electorate is high.

5. The assumption that the party most likely to win will attract more contributions is reasonable. But why do parties accept contributions if they will most probably win the election anyway? One reason can be directly extracted from one of Grossman and Helpman's (1996) assumptions: parties expect not only to be re-elected but also to maximise their seats in the legislature. Other explanations could be that parties may want to line the coffers of the party at the national level (e.g. to support or oppose federal candidates), save it for future needs or use it to retire debts from previous campaigns. Also, candidates frequently try to demonstrate their abilities as fundraisers in order to signal these qualities to voters and to their own parties.

6. The works of Ansolabehere et al. (2003) and Lowery and Gray (1997) outlined in the literature review section corroborate this possibility.

7. Interestingly, work by Eichenberger and Serna (1996) shows that information provided by electoral campaigning might alter voters' expectations even if individuals are considered rational and assess candidates and policy proposals in an unbiased way. According to them, rational voters' evaluations are subject to random errors, which - in turn - are a function of information availability. So called 'dirty information' would enlarge individuals' estimation errors. Thus, the authors conclude that electoral propaganda may change citizens' voting behaviour and aggregate political outcomes, creating 'incentives for various actors to produce dirty and clean information' (Ibid: 138). 
As the demand for lobbying increases, it is assumed that interest groups' activities and their overall influence will be strengthened within the political arena as well.

Rather than simply analyse electoral competition and voters' information separately, one should also look at the interaction of both variables when trying to explain the activities and influence of interest groups within the policy making process. It is argued that, whenever electoral competition is high, the informational level of voters will determine whether the incumbent party will choose to engage in expensive electoral campaigning or satisfy the interests of the median voter. Seriously challenged by the opposition party in the upcoming election, incumbents will try to influence as many undecided and uninformed voters as possible through campaigning. Funds are provided by interest groups who profit from the implementation of narrowly targeted policies. However, when politicians are made more accountable through the retrospective vote of informed citizens and high levels of electoral competition, incumbents try to get re-elected and maximise their representation in the legislature by enacting broad public policies that satisfy the median voter. The aggregate interests of organised groups lose importance within the parties' welfare function as the demand for contributions diminishes. In other words, parties trade campaign contributions that they might get by catering to groups' interests for a large share of votes that this may cost them among the informed voters.

\section{EMPIRICAL ANALYSIS}

Taking the fifty US states as unit of analysis, three types of dependent variables were used to empirically test the outlined hypotheses: the amount of campaign contributions, the number of registered lobbying groups and interest groups' perceived influence within the political arena of each state. This section discusses how these indicators are operationalised and presents the results of the three different statistical analyses.

\subsection{Campaign contributions}

As evidenced by the previous sections, campaign contributions play a central role within the US political system. Parties employ contributions to persuade voters through advertisements, mailing or direct contact, thereby trying to mobilize citizens to go to the polls and cast their vote. Through so called 'hard money', individuals or Political Action Committees $(P A C s)^{8}$ donate directly to

8. $P A C$ s are stand-alone organizations that collect voluntary contributions from individuals such as executives, shareholders or union members on behalf of interest groups and funnel them to the candidates and parties. 
a candidate or a political party. These contributions are regulated in source and amount. In addition, political campaigns increasingly rely on 'soft money', denoting funds that are raised and spent outside the federal election regulatory framework. This type of campaign money is donated to organizations that engage in political activity without explicitly promoting the election or defeat of a candidate. Election-related issue advocacy, for example, involves money that is not received by candidates' campaign and is used for communication associating candidates with particular issue positions (without including phrases such as 'vote for' or 'vote against').

An important principle of US campaign finance is the need to publicly disclose the received contributions. Candidate committees, party committees and $P A C$ s are required to file periodic reports revealing the money they raise and spend. ${ }^{9}$ Public financing is only available for presidential candidates. For the purpose of this article, it is also important to note that limits on campaign expenditures are considered unconstitutional on First Amendment grounds.

To capture parties' demand for campaign money, the total amount of campaign contributions to candidates of state House and Senate elections between 1995 and 1998 was employed. ${ }^{10}$ The data comes from the National Institute on Money in State Politics and is based on campaign-finance reports filed by candidates and other political parties with the state disclosure agency. ${ }^{11}$ This operationalisation directly reflects interest groups' willingness to donate and, concomitantly, parties' readiness to accept campaign funds in each single state.

\subsubsection{The Independent Variables}

The two main independent variables of interest are electoral competition and voters' level of information. Over the past years, a vivid discussion on how to measure electoral competition within the US states emerged. An indicator of electoral competitiveness that is widely adopted by political scientists is the Ranney index (Ranney, 1976). As an indicator of the degree of two-party competition in the states, it takes into account the percentage of seats won in state House, Senate and gubernatorial elections; the length of time parties controlled the governorship and the legislature; as well as the percentage of time the governorship and the legislature have been divided between the two

9. According to the McCain-Feingold law of 2002, this is also valid for soft money (especially issue advocacy). In general, the law bans national parties and federal candidates from raising and spending soft money.

10. In some states, there was no data available for the considered time span. In these few cases, campaign contributions for subsequent years (though not after 2002) were taken. Dropping these observations from all the regressions reported below did not alter the results in a substantial way.

11. The data is available at www.followthemoney.org (August $20^{\text {th }}, 2008$ ). For a description of all reported variables as well as their corresponding sources see Table A1 in the appendix. 
parties. The so called folded Ranney Index ranges from 0.5 (no competition) to 1 (perfect competition). Holbrook and Van Dunk (1993, p. 958) are critical of Ranney's index for being 'based largely on aggregate party strength in government, not on actual election results. ${ }^{12}$ The authors developed an index based on district-level outcomes of state legislative elections. The measure consists of four components: the percentage of votes going to the winning candidate, the winning candidate's margin of victory, whether the seat is 'safe' or not and whether the race was considered 'contested' or not. Despite the different composition of both indices, their correlation is considerably strong $(r$ $=0.68$. Given that Holbrook and Van Dunk's index is not readily available for the late 1990s, the folded Ranney Index for the years 1995-1998 was taken from Bibby and Holbrook (1999). ${ }^{13}$

To measure voters' level of information, the daily circulation of newspapers per person is taken for each state. As Putnam (2000, pp. 218-20) shows by using individual US data, newspaper readership contributes decisively to form wellinformed citizens with the interest and capacity to hold policy-makers accountable for their actions. Several previous studies have relied on this indicator to proxy for individuals' political informedness. Larcinese (2009, p. 262), for example, finds that the supply of news has a positive effect on political knowledge. Bruns and Himmler (2008, p. 2) affirm that newspaper readership plays 'a key role in providing voters with information about politicians'. Besley and Burgess (2002) also employ newspaper circulation to proxy for a more informed electorate. For the present cross-sectional analyses, a data set on the daily circulation of newspapers from Adserà et al. (2003, p. 475) for the year 1995 was used. The authors extracted their data from the Statistical Abstract of the United States, which gives the number of newspaper copies published in each state, and adjusted it to reflect actual readership in each state.

It has to be pointed out that employing daily newspaper readership to proxy for voters' level of information is not unproblematic. The importance and quality of the newspapers predominantly read in each state, for example, cannot be considered. Also, different patterns of newspaper readership (e.g. citizens of certain states may prefer reading about sports than about politics) could exist among the various federal units. In addition, one has to address possible omitted variables affecting both the variation of newspaper readership and interest groups' activity across states at the same time. Foremost, it seems important to rule out that daily circulation of newspaper per person is not simply a reflection of states' educational, demographical or industrial structure.

12. Individual election results are only taken into account for gubernatorial elections by the Ranney index.

13. As a longer-term phenomenon, electoral competition is relatively stable within US states over time. Note, however, that there is substantial cross-state variation, with most of the least competitive states being from the South (see Bibby and Holbrook, 2004, p. 91). 
Individuals are endowed with different capabilities to acquire news. More educated citizens are believed to face less transaction and information costs (Downs 1957; Lipset 1981). As education seemingly increases newspaper readership likeliness, states' educational attainment levels, measured by the share of the population ( 25 years or older) holding a university degree, are introduced as an important control variable. ${ }^{14} \mathrm{It}$ is assumed that more educated citizens have enhanced capabilities to control politicians, making them more accountable to the median voter and reducing their demands for lobbying money. In addition, the percentage of states' residents under 18 years of age over states' total population is considered for the year 1995. Thereby, potential variation of states' demographic structure-affecting newspaper readership and interest groups' activity at the same time - is taken into account. ${ }^{15}$

Finally, more industrialized federal units may exhibit more newspaper readers and, at the same time, spur the influence of advocacy groups. Some authors, for example, claim that the number of interest groups is concomitant to economic development. Salisbury (1975) asserts that modernisation increases groups' variety as it furthers social differentiation (see also Bischoff, 2003). To test the hypothesis that campaign contributions are higher in economically more developed states, the personal income per capita in constant dollars was taken from the Statistical Abstract of the United States for the year 1995 .

Several other control variables frequently found in the interest group literature have been included in the analysis. In order to test whether interest groups are more influential when the institutional power of incumbents is strong, a measure of governors' institutional power has been considered. Politicians with broad institutional competency supposedly reduce lobbying costs, given that the incumbent can more easily interfere in the policy making process (see Crain and Tollison, 1979). Powerful statesmen may deliver each unit of 'effective' access at lower costs, increasing groups' activities. The index for governor's power is taken from Beyle (2001) for the year 1994. It is based on six measures of institutional power - tenure, appointment power, the number of other state-wide elected officials, budget power, veto power and party control - and ranges from 0 (weak power) to 5 (strong power). ${ }^{16}$ As the dependent variable in this section measures campaign contributions accepted by candidates of State and House elections, taking governors' institutional powers can only be a rough measure over politicians' capabilities of serving

14. The data is based on the 1990 Census of Population and was extracted from the Statistical Abstracts of the United States.

15. It can be assumed that states with a younger population exhibit lower levels of newspaper readership. Data was also extracted from the Statistical Abstracts of the United States.

16. The data on gubernatorial power are available at: http://www.unc.edu/ beyle/gubnewpwr.html, (May $\left.10^{\text {th }}, 2007\right)$. 
interest groups within each state. ${ }^{17}$ For the remaining two dependent variables of this article (lobbying registrations and perceived interest group's power), Beyle's index of gubernatorial power seems better suited to assess the effect of incumbents' institutional power.

Population density in each state was taken from the Statistical Abstract of the United States for the year 1995. A high population density increases the costs of organising coalitions either to support or to oppose specific legislation, since incentives for free-riding increase (see Stigler, 1976). Therefore, contributions are expected to be higher in states with a lower population density. A second rationale for this negative relationship between both variables lies in the assumption that the more dense the population in a territory, the cheaper for a candidate to campaign.

The size of government was introduced to test the hypothesis that bigger governments increase interest groups' incentives to organise for 'buying' legislation. It is assumed that the more governments spend, the higher the total number of campaign contributions. The variable is measured by taking the total state government's expenditure per capita (US dollars) from the Statistical Abstract of the United States for the year 1996. To test whether lobbying activity are lower in states with a less diversified economy, an index of economic concentration was included. Having more diversified industries means that there is a wider variety of competing interests. Thus, the campaign contributions should rise as the number of industries increases. ${ }^{18}$ The measure compares each state's economy to the US economy, which is used as a reference. The more similar one state's economy is to the country's economy, the higher its degree of diversification. The index, taken for the year 1998, ranges from 1 to 100 ; lower values indicate that the state has a higher concentration of economic activity than the US. ${ }^{19}$

Some authors claim that the number of interest groups is concomitant to economic development. Salisbury (1975), for example, asserts that modernisation increases groups' variety as it furthers social differentiation (see also Bischoff, 2003). To test the hypothesis that campaign contributions are higher in economically more developed states, the personal income per capita in constant dollars was taken from the Statistical Abstract of the United States for the year 1995. Furthermore, the Gross State Product (GSP) for the year 1995 was also included in the model, given that bigger states are expected to exhibit more campaign contributions. ${ }^{20}$ Finally, regional dummy variables were introduced to account for possible structural instability.

17. Unfortunately, indicators of State and House candidates' institutional power are not readily available across US states.

18. See Dahl and Tufte (1973)

19. The index of economic diversity was retrieved from the Bureau of Economic Analysis, Division of Insurance.

20. The GSP was also extracted from the Statistical Abstracts of the United States. 


\subsubsection{Results}

Table I below reports the results of a cross-sectional analysis for 49 US states employing OLS estimations and robust standard errors. Nebraska had to be excluded from the analysis, since the state makes use of non-partisan state legislative elections and, thus, no Ranney index can be calculated for this observation. Campaign contributions - the dependent variable - was taken for the years 1995 to $1998 .{ }^{21}$ In order to normalise the distribution of the dependent variable, the log of campaign contribution was taken. A Cook and Weisberg test for heteroscedasticity indicates that the Null Hypothesis of constant error variance cannot be rejected.

Two main findings can be extracted from model 1 . Contrary to the prediction derived from Grossman and Helpman's model, a concentration of interest groups on the 'winning' party in times of undisputed political races does not seem to increase the total number of campaign contributions within a state. In fact, the analysis shows that lobbying money is positively associated with electoral competition, corroborating the findings of Ansolabehere et al. (2003). Close races seem not to restrain special interest groups from making donations to their favourite candidate. The coefficient for electoral competition is positive and highly significant. Besides, the effect magnitude is considerably large, as shown by the standardized coefficients reported in model 3. Contributions increase by approximately 3,8 standard deviations with each one-standarddeviation increase in the Ranney index.

This interpretation, however, is not sustained when the quadratic function of electoral competition is introduced in model 2 in order to account for possible non-linearities. As can be noted, low levels of competition are positively associated with campaign contributions. In contrast, a competitive environment - captured by the squared term - seems to reduce lobbying money. Thus, the effect is curvilinear: while electoral competition first increases contributions, it decreases them after a certain threshold is reached. Rising uncertainty over the election result may indeed lower campaign contributions' effectiveness, increasing the lobbying costs. It may be more expensive to 'buy' legislation under highly competitive systems. The estimated turning point - calculated by dividing the negative value of the linear term by two times the value of the squared term - is around 0,91 , thereby lying within the sample's range (the sample's Ranney index ranges from $0,699$ to 0,993$){ }^{22}$

The main conclusion drawn from this analysis, however, is that an informed electorate reduces the total amount of campaign contributions. This finding

21. The different independent variables were taken for the time periods reported in the previous section.

22. A total of 20 states figure above this cut-off point. 
Table I

Dependent Variable: Log of Campaign Contributions

\begin{tabular}{|c|c|c|c|}
\hline Variables & Model 1 & Model 2 & Model 3 (stand. coef.) \\
\hline electoral competition & $\begin{array}{l}3.23 \\
(1.36)^{* *}\end{array}$ & $\begin{array}{l}53.43 \\
(26.56)^{* *}\end{array}$ & $3.76^{* *}$ \\
\hline Electoral competition Squared & & $\begin{array}{l}-29.36 \\
(15.60)^{*}\end{array}$ & $-3.55^{*}$ \\
\hline newspaper readership & $\begin{array}{l}-7.63 \\
(3.35)^{* *}\end{array}$ & $\begin{array}{l}-7.27 \\
(3.10)^{* *}\end{array}$ & $-0.24^{* *}$ \\
\hline Higher Education & $\begin{array}{l}-0.14 \\
(0.05)^{* * *}\end{array}$ & $\begin{array}{l}-0.13 \\
(0.04)^{* * *}\end{array}$ & $-0.41^{* * *}$ \\
\hline Population under 18 & $\begin{array}{c}0.002 \\
(0.05)\end{array}$ & $\begin{array}{r}-0.007 \\
(0.05)\end{array}$ & -0.01 \\
\hline size of government & $\begin{array}{l}-1.78^{*} 10^{-5} \\
\left(9.8^{*} 10^{-5}\right)\end{array}$ & $\begin{array}{l}-1.40^{*} 10^{-4} \\
\left(9.89^{*} 10^{-5}\right)\end{array}$ & -0.11 \\
\hline population density & $\begin{array}{c}9.2^{*} 10^{-5} \\
\left(5.64^{*} 10^{-4}\right)\end{array}$ & $\begin{array}{r}1.94^{*} 10^{-4} \\
\left(5.75^{*} 10^{-4}\right)\end{array}$ & -0.04 \\
\hline power of governors & $\begin{array}{c}0.313 \\
(0.30)\end{array}$ & $\begin{array}{c}0.331 \\
(0.30)\end{array}$ & 0.11 \\
\hline gross state product & $\begin{array}{l}0.003 \\
(0.001)^{* * * *}\end{array}$ & $\begin{array}{l}0.004 \\
(0.001)^{* * * *}\end{array}$ & $0.50^{* * * *}$ \\
\hline Economic diversity & $\begin{array}{l}0.02 \\
(0.009)^{* *}\end{array}$ & $\begin{array}{l}0.01 \\
(0.009)\end{array}$ & 0.18 \\
\hline Economic development & $\begin{array}{c}1.75^{*} 10^{-4} \\
\left(6.12^{*} 10^{-5}\right)^{* * *}\end{array}$ & $\begin{array}{c}1.78^{*} 10^{-4} \\
\left(5.67^{*} 10^{-5}\right)^{* * *}\end{array}$ & $0.48^{* * *}$ \\
\hline West & $\begin{array}{c}0.18 \\
(0.28)\end{array}$ & $\begin{array}{c}0.35 \\
(0.28)\end{array}$ & 0.12 \\
\hline South & $\begin{array}{c}0.22 \\
(0.35)\end{array}$ & $\begin{array}{c}0.34 \\
(0.35)\end{array}$ & 0.13 \\
\hline Constant & $\begin{array}{l}9.83 \\
(2.76)^{* * *}\end{array}$ & $\begin{array}{r}-11.21 \\
(11.43)\end{array}$ & \\
\hline $\begin{array}{l}\text { Number of Obs. } \\
\mathrm{R}^{2}\end{array}$ & $\begin{array}{r}49 \\
0.775\end{array}$ & $\begin{array}{c}49 \\
0.793\end{array}$ & \\
\hline Prob $>F$ & 0.0000 & 0.0000 & \\
\hline
\end{tabular}

Note: OLS regressions using robust standard errors. Standard errors in parentheses.

**** significant for $\mathrm{p}<0,001 ;{ }^{* * *} \mathrm{p}<0,01 ;{ }^{* *} \mathrm{p}<0,05 ;{ }^{*} \mathrm{p}<0,1$

corroborates the intuition that raising campaign money loses its effectiveness as an instrument of securing political power whenever citizens are better informed. As assumed by Baron (1994, p. 33), uninformed voters seem not to know the policy positions of the candidates, 'and their vote is influenced by campaign expenditures'. Campaign spending seems to be an effective instrument of influencing the uninformed voter. ${ }^{23}$ Note that the negative and

23. The outlined directly-informative models put forward by Coate (2004) or Ashworth (2006) would most likely interpret this negative association between citizens' information and campaign spending in a different manner. Following the models' assumptions, low voter information would lead to a greater demand for election-relevant information. This information could be provided by campaign advertising, possibly increasing aggregated welfare. Considering the results on voters' informedness 
significant coefficient for voter's informedness is not a mere reflection of citizen's higher education. The variable measuring the percentage of states' population holding a university degree also features a negative sign and is highly significant. Thus, it seems that both more informed and as well more educated electors prevent politicians from catering to special interests.

As shown by the standardized coefficients in model 3 , the coefficient's magnitude of the variable reflecting higher education is comparable to those of gross state product or economic development (only the effect of electoral competition being substantively higher). A one percent increase of university graduates within a state reduces lobbying money by around $12 \% .{ }^{24}$ The effect of newspaper circulation is also substantial. When increasing the daily circulation of newspapers per person by 0,1 points - which corresponds to the difference found between Virginia and Maine - campaign contributions decrease by approximately $52 \%{ }^{25}$

Two control variables turned out to be statistically significant. As predicted, bigger states - as measured by the gross state product - are associated with more lobbying money. This result is not particularly surprising, as bigger federal units may count on more donors and, thus, may disburse more money on electoral campaigning. More striking is the finding that larger states seem to spend less lobbying money on a per capita basis. Once contributions per capita is used as dependent variable, the variable measuring the gross state product becomes negative and is statistically significant on the $10 \%$-level. ${ }^{26}$ In addition, economically more developed states also exhibit more campaign contributions, corroborating Salisbury's (1975) claim that groups' activities are concomitant to economic development. All remaining variables turned out to be nonsignificant.

\subsubsection{Endogeneity}

The results above indicate that voters' information and education are possibly a key determinant for the quality of political representation. Furthermore, electoral competition seems to constrain politicians' ability to demand campaign contributions in a non-monotonic way. However, one still has to account for the possibility that electoral competition is endogenous to interest groups' activity. By donating considerable amounts of money to the challenging party,

and the perceived interest groups' influence to be reported subsequently, the intuition that the uninformed median voter loses vis-à-vis special interests groups appears more plausible though.

24. Given that the dependent variable is log-transformed, the effect size is calculated by $\exp (-0.13)=$ 0.878 .

25. This effect size was calculated in the following way: $\exp (-7.27 / 10)=0.483$.

26. This result - not extensively reported here due to space constrains - can be accessed through a web appendix available at http://www.polver.uni-konstanz.de/gschneider/mitarbeiter/dr-tim-wegenast. 
interest groups may e.g. spur inter-party competition. As correctly summarized by Stratmann (2005, p. 138), 'while spending influences the vote share, the expected vote share may influence spending'.

Empirical evidence on the possible effect of campaign expenditures on the competitiveness of electoral systems is scarce and inconclusive. Hogan (2001) asserts that incumbents who manage to raise a lot of contributions prior to a campaign may scare off potential challengers, diminishing electoral competition (see also Goodliffe, 2001). Theoretical, formal and empirical work suggests that limits on campaign contribution can make races more competitive (Coate, 2004; Stratmann and Aparicio-Castillo, 2006). Levitt (1994), in contrast, finds no statistically significant correlation between incumbent campaign spending and incumbent vote share.

Ansolabehere et al. (2003) and Artés and Vinuela (2007) invert the causality of the relationship and affirm that electoral competition increases campaign spending. Both studies employ panel data to better assess the effect of electoral competition on campaign expenditures. By exploring the time dimension of their data, the authors have a better grasp over the direction of causality. However, none of the cited studies address this endogeneity issue in greater detail, e.g. by instrumenting one of the variables. This may lie in the fact that finding an instrument that is exogenous to one, but endogenous to the other variable is very difficult, if not to say impossible. Thus, the achieved results concerning the effect of electoral competition on interest groups' activity should be interpreted with caution. Future work disentangling the relationship between both variables appears indispensable.

The possibility that voter's level of information is a function of campaign spending has to be addressed as well. Newspaper readership may be conditioned upon interest groups' activities. In order to try to minimize this endogeneity issue within the regression analyses, daily circulation of newspaper was taken for the year 1995, while total campaign contributions were collected for the period 1995-1998. Furthermore, when newspaper circulation - as dependent variable - is regressed on campaign contributions, no reversed association can be detected.

\subsection{Lobbying registrations}

It is meaningful to check the robustness of the previous results considering alternative operationalisations for interest groups' activity. Besides their effect on campaign contributions, electoral competition and voters' level of information are also believed to influence communities' readiness to formally register as interest groups. Parties' increasing demand for lobbying is expected to raise the total number of lobbying registration within a state. Gray and Lowery 
(1996, 2001) and Gray et al. (2005) compiled state lobby registration lists gathered by mail or by web pages from state agencies. The authors coded the organisations registered to lobby on several dimensions, 'including organizational type (institution, membership group, or association) and interest content (27 categories of substantive interest), using directories of organizations, associations, and groups and the web pages of individual organizations' (Gray and Lowery, 2001, p. 267). For the present analysis, the total number of lobbying registration from profit-oriented organisations within each of the 50 US states was employed for the year $1999 .{ }^{27}$ It is worth noting that the correlation between both indicators of interest groups' activity (campaign contributions and lobbying registrations) is high $(r=0,68)$.

The independent variables remain identical to the ones employed before. With the exception of the Ranney index, which covers the period between 1995 and 1998, all other predictors were taken for the year $1998 .^{28}$ The dependent variable was transformed into its logarithm to normalise its distribution. A Cook and Weisberg test once more showed no incidence of heteroscedasticity. Table II below reports the results of two different model specifications. Largely, the new coefficients confirm the findings of the previous analysis.

Again, voters' level of information seems to constrain interest groups' activity, decreasing the total amount of lobbying registrations. Although presenting smaller standardized coefficients than most of the other independent variables (see model 3 ), the estimation shows that registrations decline by approximately $21 \%$ with each 0,1 point increase of daily newspaper circulation per capita. Higher shares of university graduates within each state are associated with reduced registrations as well. A one percentage increase in states' university graduates reduces total lobbying registrations by approximately $16 \%$.

Also in line with the results for campaign contributions, electoral competition significantly increases the amount of states' registration numbers. When a quadratic function is introduced in model 2 , a curvilinear effect between lobbying registration and competition becomes noticeable as in Table I. Note, however, that both terms capturing the nonlinear effect are not statistically significant.

The variables measuring gross state product and states' economic development remain positive and highly significant. In addition, three other control variables achieved statistical significance under this new dependent variable. As expected, economically more diverse states are associated with more lobbying registrations. Other than hypothesised above, however, large states

27. The data was kindly provided by David Lowery. For a more detailed description of how the data was generated see Gray and Lowery (1996). While the total number of lobbying registrations increased steadily from 1980 to 1997 (see Gray and Lowery, 2001), inter-state differences remained stable.

28. All data sources remain identical as well. 
Table II

Dependent Variable: Log of Lobbying Registrations

\begin{tabular}{|c|c|c|c|}
\hline Variables & Model 1 & Model 2 & Model 3 (stand. coef.) \\
\hline electoral competition & $\begin{array}{l}1.61 \\
(0.78)^{* *}\end{array}$ & $\begin{array}{c}4.86 \\
(17.61)\end{array}$ & 0.63 \\
\hline Electoral competition Squared & 100.07 & $\begin{array}{l}-1.89 \\
(10.41)\end{array}$ & -0.43 \\
\hline newspaper readership & $\begin{array}{l}-2.46 \\
(1.08)^{* *}\end{array}$ & $\begin{array}{l}-2.41 \\
(1.13)^{* *}\end{array}$ & $-0.18^{* *}$ \\
\hline Higher Education & $\begin{array}{l}-0.06 \\
(0.02)^{* * *}\end{array}$ & $\begin{array}{l}-0.06 \\
(0.02)^{* * *}\end{array}$ & $-0.33^{* * *}$ \\
\hline Population under 18 & $\begin{array}{l}0.07 \\
(0.04)^{*}\end{array}$ & $\begin{array}{c}0.07 \\
(0.04)^{*}\end{array}$ & $0.21^{*}$ \\
\hline size of government & $\begin{array}{c}-1.3^{*} 10^{-4} \\
\left(4.5^{*} 10^{-5}\right)^{* * *}\end{array}$ & $\begin{array}{c}-1.3^{*} 10^{-} 4 \\
\left(5.7^{*} 10^{-} 5\right)^{* *}\end{array}$ & $-0.19^{* *}$ \\
\hline population density & $\begin{array}{c}2.1^{*} 10^{-4} \\
\left(2.7^{*} 10^{-4}\right)\end{array}$ & $\begin{array}{c}2.0^{*} 10^{-4} \\
\left(2.7^{*} 10^{-4}\right)\end{array}$ & 0.08 \\
\hline power of governors & $\begin{array}{r}-0.01 \\
(0.15)\end{array}$ & $\begin{array}{r}-0.01 \\
(0.16)\end{array}$ & -0.005 \\
\hline gross state product & $\begin{array}{l}0.001 \\
(0.0005)^{* *}\end{array}$ & $\begin{array}{l}0.001 \\
(0.0005)^{* *}\end{array}$ & $0.42^{* *}$ \\
\hline Economic diversity & $\begin{array}{l}0.01 \\
(0.006)^{* *}\end{array}$ & $\begin{array}{l}0.01 \\
(0.007)^{*}\end{array}$ & $0.33^{*}$ \\
\hline Economic development & $\begin{array}{c}8.8^{*} 10^{-5} \\
\left(3.1^{*} 10^{-5}\right)^{* * *}\end{array}$ & $\begin{array}{c}8.8^{*} 10^{-5} \\
\left(3.15^{*} 10^{-5}\right)^{* * *}\end{array}$ & $0.44^{* * *}$ \\
\hline West & $\begin{array}{r}-0.06 \\
(0.16)\end{array}$ & $\begin{array}{c}-0.04 \\
(0.16)\end{array}$ & -0.03 \\
\hline South & $\begin{array}{r}-0.06 \\
(0.21)\end{array}$ & $\begin{array}{r}-0.05 \\
(0.23)\end{array}$ & -0.03 \\
\hline Constant & $\begin{array}{c}1.64 \\
(1.49)\end{array}$ & $\begin{array}{c}0.26 \\
(7.70)\end{array}$ & \\
\hline $\begin{array}{l}\text { Number of Obs. } \\
\mathrm{R}^{2} \\
\text { Prob }>\mathrm{F}\end{array}$ & $\begin{array}{l}\quad 49 \\
0.751 \\
0.0000\end{array}$ & $\begin{array}{l}\quad 49 \\
0.751 \\
0.0000\end{array}$ & . \\
\hline
\end{tabular}

Note: OLS regressions using robust standard errors. Standard errors in parentheses.

${ }^{* * * *}$ significant for $\mathrm{p}<0,001 ;{ }^{* * *} \mathrm{p}<0,01 ;{ }^{* *} \mathrm{p}<0,05 ;{ }^{*} \mathrm{p}<0,1$

seem to reduce the number of advocacy groups registered within each federal unit. This is rather surprising, given that large governments are believed to spur groups' incentives to organize. Furthermore, states exhibiting a younger population show increased interest groups' activity (this result, however, being significant only at the $10 \%$ level).

All the results reported in Tables I and II are robust to the inclusion or exclusion of different sets of independent variables. ${ }^{29}$ Additional robustness checks showed that the reported coefficients are also not driven by

29. In addition to the independent variables reported here, other possible determinants of campaign contributions such as ethnic diversity, ballot access restrictions, urbanization rate, social capital or partisanship were considered. 
single outliers. ${ }^{30}$ A stepwise inclusion of all independent variables indicated that the reported findings are unlikely to be driven by multicollinearity. This is confirmed by an analysis of predictors' variance inflation factor (VIF). The analysis indicated that Chatterjee and colleagues' (2000) criteria for the presence of multicollinearity are not met, suggesting that the independent variables do not suffer from high linear relationship among each other. $^{31}$

\subsection{Interest groups' perceived influence}

So far, direct measures of groups' activity have been employed to try to assess under what electoral conditions do political parties increasingly value special interests within their utility functions. To further test the hypotheses outlined in the beginning of this paper, the perceived power of interest groups within state politics will be considered as well. The data for the last dependent variable comes from a project on American interest groups coordinated by Clive Thomas and Ronald Hrebenar (see Thomas and Hrebenar, 2004). The authors provide a set of five binary dummies reflecting the perceived importance of interest group involvement in the policymaking of each state.

The established categories are the following: 'dominant' (when interest groups in the state primarily determine the policy agenda and of policy outcomes virtually all of the time), 'complementary' (where interest groups 'work in conjunction with other aspects of the political system') (Thomas and Hrebenar, 1999, p. 12), 'subordinate' (where the interest group system is subordinate to all other political institutions when it comes to determining the policy agenda), 'dominant/complementary' and 'complementary/subordinate' (where interest groups alternate between the two categories or they are in the process of moving from one to the other') (Ibid, p. 14). Since no state is classified as 'subordinate', the variable IPOWER has only four possible outcomes that range from 2 (subordinate/complementary) to 5 (dominant). The authors' classification builds upon a survey method developed by Zeller (1954) as well as Morehouse (1981). Questionnaires were sent to four or five knowledgeable people in each of the 50 US states, most of whom were political scientists. Additionally, questionnaires were also sent to public officials. In order to classify interest group influence according to the categories exposed

30. As estimations employing ordinary least squares (OLS) tend to track outliers, estimators that are less sensitive to the pull of outliers were equally used (robust regressions). The results from these robustness checks were also summarized in the web appendix.

31. Chatterjee et al. (2000) suggest the following guideline for the presence of multicollinearity: The largest VIF is greater than 10 or the mean VIF is larger than 1. 
above, content analysis was used. Other studies, such as Shughart et al. (2003), made use of the described data.

The next cross-sectional analysis assesses the impact of the previous independent variables on the perceived overall groups' strength within state politics. The variable representing groups' influence was taken for the mid 1980s from Thomas and Hrebenar (1999, p. 13). For the period of time considered, measures of electoral competition - believed to be more valid than Ranney's index - are available. Thus, a measure of legislative competition provided by Smith (1998), who combines the methods described in Holbrook and Van Dunk (1993) and Van Dunk and Weber (1997) was used. The index, based on states' legislative elections, has three components, aggregated across districts within a state: the margin in the district, a dummy for whether both parties contested the seat and a dummy for whether the seat is safe (defined as a margin over 10 points). It ranges between 0 and 100 (with higher values indicating more electoral competition) and was taken for the period $1980-1984 .{ }^{32}$ Sources for the variables newspaper readership and higher education (observed as of 1983), governors' institutional power (observed as of 1980), populations' density, gross state product, per capita income (observed as of 1985) as well as size of government (observed as of 1982) remain identical. The economic diversity measure, reflective of 1982, was taken from Wagner and Deller (1998, p. 550).

Since the dependent variable is polychotomous and can be placed in a natural order, an ordinal logit model was used to estimate the 1980s cross section. ${ }^{33}$ Estimations were done using normal standard errors as well as White and Huber's heteroscedastic-robust standard errors (see White, 1980). Regional dummies were included to test for structural instability. A Wald test by Brant (1990) was applied in order to test the important assumption, implicit in the ordinal regression model, that the slope coefficients are identical across regressions for each outcome of the dependent variable (proportional odds assumption). The test indicated no need to consider alternative models that do not impose the constraint of parallel regressions.

Table III below reports the effect of the former dependent variables on the perceived influence of interest groups. Scalar measures of fit have been computed in order to better value the obtained goodness of fit (Pseudo $\left.\mathrm{R}^{2}\right) \cdot{ }^{34}$ Likelihood Ratio Tests of the estimated model against several nested models showed that the full model has a proper specification.

32. Data was kindly provided by Mark Smith. Alternatively to Smith's measure, the Ranney index was also employed in all regressions reported below. Results remained unaltered.

33. All regression models presented in this section were also calculated using probit estimation. Since results did not differ significantly, they are not reported in the paper.

34. Windmeijer (1995) notes that, for ordinal outcomes, McKelvey and Zavonia's $\mathrm{R}^{2}$ most closely approximate the $\mathrm{R}^{2}$ obtained by estimating the linear regression model on the underlying latent variable. 
Table III

Dependent Variable: Perceived Interest Groups' Influence

\begin{tabular}{|c|c|c|}
\hline Variables & Model I & Model II (odds ratios) \\
\hline electoral competition & $\begin{array}{c}0.03 \\
(0.16)\end{array}$ & 1.03 \\
\hline electoral competition squared & $\begin{array}{r}-0.001 \\
(0.001)\end{array}$ & 0.999 \\
\hline newspaper readership & $\begin{array}{c}-10.55 \\
(6.05)^{*}\end{array}$ & $2.62^{*} 10^{-5^{*}}$ \\
\hline Higher education & $\begin{array}{l}-0.37 \\
(0.17)^{* *}\end{array}$ & $0.693^{* *}$ \\
\hline size of government & $\begin{array}{l}0.001 \\
(0.0006)^{* *}\end{array}$ & $1.001^{* *}$ \\
\hline population density & $\begin{array}{r}-0.0004 \\
(0.004)\end{array}$ & 1.0004 \\
\hline power of governors & $\begin{array}{l}0.16 \\
(0.79)\end{array}$ & 1.18 \\
\hline gross state product & $\begin{array}{c}7.49 e^{-6} \\
\left(3.13 e^{-6}\right)^{* *}\end{array}$ & $1.00001^{* *}$ \\
\hline Economic diversity & $\begin{array}{c}0.37 \\
(5.87)\end{array}$ & 1.45 \\
\hline Economic Development & $\begin{array}{r}-0.0005 \\
(0.0005)\end{array}$ & 0.9995 \\
\hline West & $\begin{array}{l}3.23 \\
(1.12)^{* * *}\end{array}$ & $25.21^{* *}$ \\
\hline South & $\begin{array}{l}1.75 \\
(2.71)\end{array}$ & 5.78 \\
\hline _cut1 & $\begin{aligned}- & 13.56 \\
& (8.99)\end{aligned}$ & \\
\hline _cut2 & $\begin{array}{r}-9.75 \\
(9.00)\end{array}$ & \\
\hline _cut3 & $\begin{array}{r}-6.35 \\
(9.12)\end{array}$ & \\
\hline Number of Obs. & 50 & \\
\hline $\begin{array}{l}\text { Pseudo } \mathrm{R}^{2} \\
\text { McKelvey and Zavoina's } \mathrm{R}^{2}\end{array}$ & $\begin{array}{l}0.380 \\
0.685\end{array}$ & \\
\hline Prob $>\mathrm{chi}^{2}$ & 0.0000 & \\
\hline
\end{tabular}

Note: Ordered logit regression employing robust standard errors (shown in parentheses).

**** significant for $\mathrm{p} \leq 0,001 ;{ }^{* * *} \mathrm{p}<0,01 ;{ }^{* *} \mathrm{p}<0,05 ;{ }^{*} \mathrm{p}<0,1$

As evident, citizens' level of information is associated with reduced group influence in state politics, underlying the core intuition that interest groups lose weight within parties' utility function whenever politicians are made accountable by an informed electorate. As evident by the odd ratios reported in model 2 , however, the effect size is small. Again, individuals' educational attainment has a strong negative effect on interest groups' power. The odd ratio shows that a one percent increase in graduate students make it around 20 percent less likelier to find moderately strong, strong or very strong interest groups within a state (compared to weak interest groups).

Electoral competition maintains its curvilinear effect, first increasing special interests power and then suppressing it after a certain threshold is reached. 
Figure I

Predicted Probabilities for single interest group's type at a high level of newspaper circulation

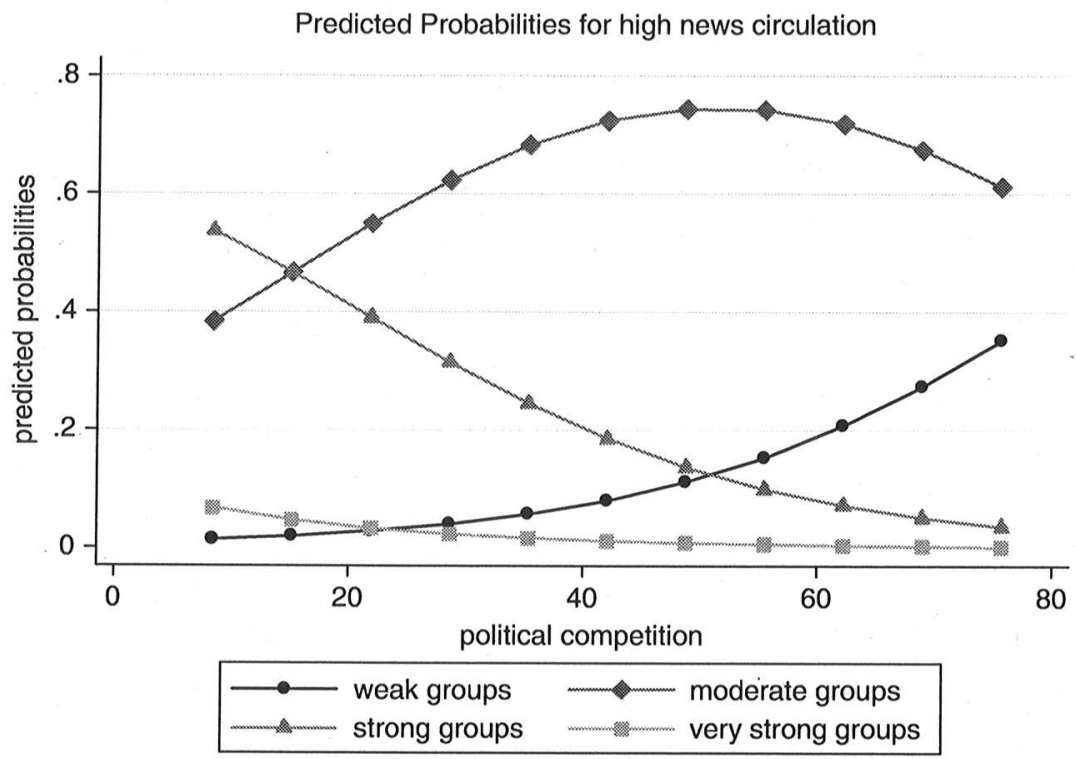

Given the chosen lag structure between political competition and groups' perceived influence, these findings are less likely to suffer from potential reversed causality problems. ${ }^{35}$ Note, however, that both coefficients for electoral competition are not statistically significant.

The joint effect of electoral competition and voters' level of information on interest group strength is explored by plotting the predicted probabilities for changing values of electoral competition with newspaper readership set at a high $(0,40)$ and a low level $(0,16)$, maintaining all other variables at their means. Most striking is that while probabilities for having strong interest groups ('dominant/ complementary') grow when voters are rather uninformed (Figure II), they fall steadily with increasing electoral competition in an environment of informed citizens (Figure I). This finding corroborates the underlying rationale that under such circumstances-interest groups lose importance within state politics. In these situations, parties seem to prefer satisfying median voters' interests, given that catering to special interests would cost too many votes among the informed electorate. As suggested, voters' information indeed seems to play a

35. In addition, regressing interest groups' power on electoral competition did not yield significant results. 
Figure II

Predicted Probabilities for single interest group's type at a low level of newspaper circulation

Predicted Probabilities for low news circulation

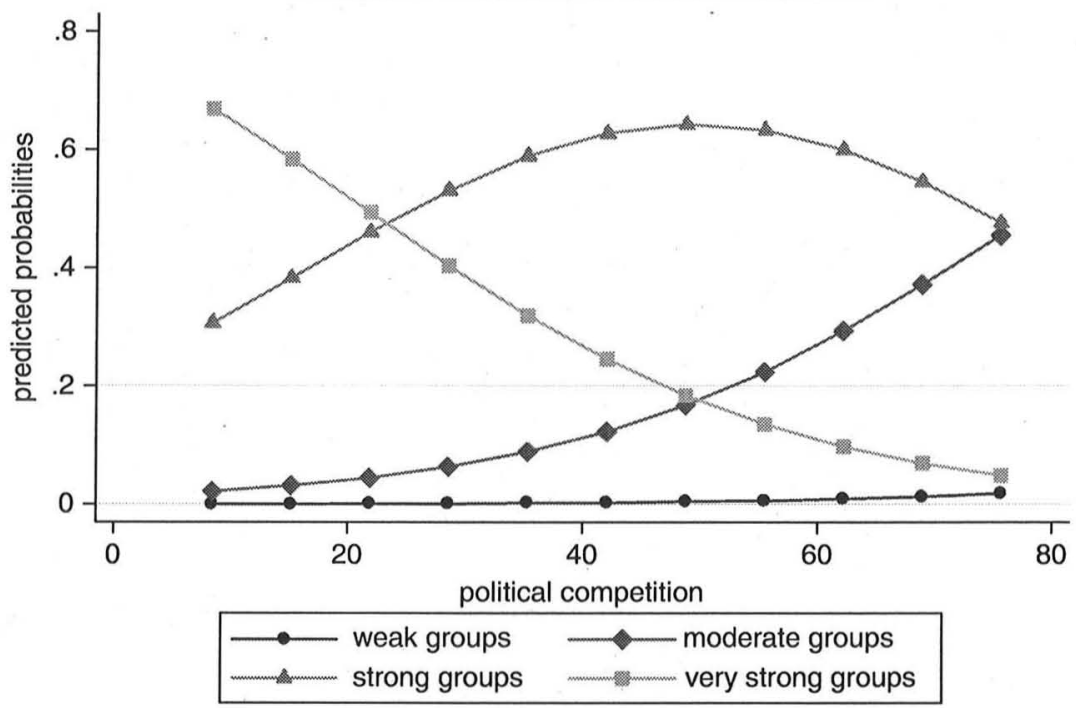

pivotal role in contexts of increased electoral competition, determining the size of governments' demand for lobbying activities. Furthermore, Figure II reveals that parties cannot explore voters' lack of information indefinitely. Once a certain threshold of electoral competition is achieved (around 50), the predicted probabilities for having strong interest groups start to fall.

Another interesting finding is that very influential interest groups ('dominant') are unlikely to be found whenever political competition is high, independent of the level of newspaper readership. Thus, while an environment of close electoral races and uninformed voters increases the likelihood of having influential groups, it decreases probabilities of finding very influential ones. When electoral races are perceived as being close by competing parties, incumbents wanting to impress a large share of uninformed voters may only exchange campaign contributions for narrowly-targeted policies up to a certain point. In such a situation and following the classification by Thomas and Hrebenar (2004), groups are expected to be 'dominant/complementary' but not completely 'dominant' as predicted by the third hypothesis postulated in section 4 .

Three control variables reach statistical significance at conventional levels. As in the two former analyses, the probabilities of finding more influential interest groups in bigger states - as measured by the gross state product-are considerably higher. Also, while bigger public sectors were associated with less lobbying 
registrations in the former analysis, they seem to spur groups' influence. Thus, it is possible that government spending consolidate the total number of advocacy groups while, at the same time, furthering special groups' influence. Finally, being a Western state strongly increases the probability of finding powerful groups.

\section{CONCLUSIONS}

Many theorists have connected interest groups' influence-seeking with several governmental activities such as policy regulation or spending. However, the determinants of interest group influence have hardly been tested in a direct way. This paper contributed to this line of research by studying contextual variables that affect interest groups' influence within political systems. Following the most important findings of this paper, better informed citizens diminish the perceived overall power of interest groups, the total number of lobbying registration as well as the amount of campaign contributions, other things equal. Education appears to constrain special interest groups as well, as it decreases lobbying money within states. In this sense, informed and educated citizen seem to constitute an effective method of holding incumbent politicians accountable for their actions.

While the results for voters' level of information are in line with Grossman and Helpman's model, the relationship between electoral competition and the three indicators of interest groups' activity proved to be curvilinear. Campaign contributions, the number of lobbying registrations and groups' perceived influence are first positively associated with electoral competition, but fall once races become more competitive. Thus, some evidence could be found for the authors' assumption that, by concentrating on the 'winning' party, interest groups increase the total amount of campaign contributions whenever elections' results are predictable. However, this finding should be interpreted with care, as the coefficients for electoral competition are only significantly associated with campaign contributions and the possibility of reversed causality cannot be fully ruled out.

Finally, evidence was presented for a combined effect of inter-party competition and voters' level of information on the importance of special interest groups within the US. Logistic regressions showed that predicted probabilities for finding strong or very strong interest groups within state politics in a context of competitive elections and informed voters are very low. The applied framework attributed a pivotal role to electors' amount of information whenever races are contested. As has been outlined, politicians face a trade-off between enacting broadly-targeted public policies aimed at the median voter or catering to special interests in order to maximise their political power. The findings suggest that parties increasingly value the first of the two instruments when political competition and information among voters are high. 
There are still many questions to be answered in future research. It appears essential, for example, to better disentangle the relationship between political competition and interest groups' activities, paying more attention to the precise directions of causality. More work on how effective electoral campaigns are at convincing uninformed and undecided voters appears necessary as well. Also, it would be meaningful to explore groups' reactions whenever they face uncertainty over elections' results in greater detail. Do they split contributions, grant unconditional gifts to affect the probabilities of elections or simply refrain from donating? Finally, more empirical tests and theoretical justifications have to be provided for a possible curvilinear effect between electoral competition and lobbying activities. In-depth case-study of interest groups' donation strategies would elicit greater insight into the plausibility of Grossman and Helpman's assumptions.

Considering the unequal representation of interests within US society, some policy recommendations can be proposed based on the obtained results. The importance of having educated and informed citizens for the democratic process once more is stressed by the present analysis. Solid educational policies and unbiased channels of information seem indispensable to strengthening citizenship and overcoming the 'bias of representation' observable within US politics. Also, the analysis evidenced that there are good reasons to suspect that the overall importance of interest groups is weakened in favour of other forms of democratic political participation with increasing electoral competition. In this case, institutional factors enhancing competition between parties should be given special attention. While reforming the US electoral system, measures such as more public funding programs for state and local elections, lower-cost advertising time on television or changes in states' registration laws or in the redistricting system should be considered. 


\section{APPENDIX}

Table AI

Variable Definitions and Data Sources

\begin{tabular}{|c|c|c|}
\hline Variable & Definition & Source \\
\hline Campaign contributions & $\begin{array}{l}\text { total amount of campaign contribu- } \\
\text { tions to candidates of state House } \\
\text { and Senate elections between } 1995 \\
\text { and } 1998\end{array}$ & $\begin{array}{l}\text { National Institute on Money } \\
\text { in State Politics, http://www. } \\
\text { followthemoney.org }\end{array}$ \\
\hline Lobbying registrations & $\begin{array}{l}\text { total number of lobbying registra- } \\
\text { tion from profit-oriented organisa- } \\
\text { tions in the year } 1999\end{array}$ & Gray and Lowery (2001) \\
\hline $\begin{array}{l}\text { Interest groups' } \\
\text { influence }\end{array}$ & $\begin{array}{l}\text { dummies reflecting the perceived } \\
\text { importance of interest group } \\
\text { involvement in the policymaking } \\
\text { of each state in the year } 1985\end{array}$ & Thomas and Hrebenar (1999) \\
\hline $\begin{array}{l}\text { Electoral competition } \\
\text { (Table I and II) }\end{array}$ & $\begin{array}{l}\text { Folded Ranney Index for the years } \\
1995-1998\end{array}$ & Bibby and Holbrook (1999) \\
\hline $\begin{array}{l}\text { Electoral competition } \\
\text { (Table III) }\end{array}$ & $\begin{array}{l}\text { the winning margin in the district, a } \\
\text { dummy for whether both parties } \\
\text { contested the seat and a dummy for } \\
\text { whether the seat is safe (1980-1984) }\end{array}$ & Smith (1998) \\
\hline Newspaper readership & $\begin{array}{l}\text { daily circulation of newspapers per } \\
\text { person }\end{array}$ & $\begin{array}{l}\text { Adserà et al. (2003) and Statistical } \\
\text { Abstract of the United States }\end{array}$ \\
\hline Higher Education & $\begin{array}{l}\text { share of population ( } 25 \text { years or } \\
\text { older) holding an university degree }\end{array}$ & $\begin{array}{l}\text { Statistical Abstract of the United } \\
\text { States }\end{array}$ \\
\hline Population under 18 & $\begin{array}{l}\text { share of the population under } 18 \\
\text { years of age }\end{array}$ & $\begin{array}{l}\text { Statistical Abstract of the United } \\
\text { States }\end{array}$ \\
\hline Power of governors & $\begin{array}{l}\text { Measure of institutional power of } \\
\text { governors considering tenure, ap- } \\
\text { pointment power, the number of } \\
\text { other state-wide elected officials, } \\
\text { budget power, veto power and party } \\
\text { control }\end{array}$ & $\begin{array}{l}\text { Beyle (2001), http://www.unc.edu/ } \\
\sim \text { beyle/gubnewpwr.html }\end{array}$ \\
\hline Population density & $\begin{array}{l}\text { Population per square mile of } \\
\text { land area }\end{array}$ & $\begin{array}{l}\text { Statistical Abstract of the United } \\
\text { States }\end{array}$ \\
\hline Size of government & $\begin{array}{l}\text { state government's expenditure } \\
\text { per capita (US dollars) }\end{array}$ & $\begin{array}{l}\text { Statistical Abstract of the United } \\
\text { States }\end{array}$ \\
\hline $\begin{array}{l}\text { Economic diversity } \\
\text { (Table I and II) }\end{array}$ & index of economic concentration & $\begin{array}{l}\text { Bureau of Economic Analysis, } \\
\text { Division of Insurance }\end{array}$ \\
\hline $\begin{array}{l}\text { Economic diversity } \\
\text { (Table III) }\end{array}$ & index of economic concentration & Wagner and Deller (1998) \\
\hline Economic development & $\begin{array}{l}\text { personal income per capita in } \\
\text { constant dollars }\end{array}$ & $\begin{array}{l}\text { Statistical Abstract of the United } \\
\text { States }\end{array}$ \\
\hline Gross state & & $\begin{array}{l}\text { Statistical Abstract of the United } \\
\text { States }\end{array}$ \\
\hline
\end{tabular}


Table AII

Descriptive Statistics

\begin{tabular}{lcccc}
\hline Variable & Min & Max & Mean & Standard Deviation \\
\hline Campaign contributions (log) & 11.63 & 17.92 & 15.04 & 1.21 \\
Lobbying registrations (log) & 4.11 & 7.44 & 6.08 & 0.65 \\
Interest groups' influence & 2 & 5 & 3.6 & 0.90 \\
Electoral competition & 0.699 & 0.993 & 0.864 & 0.085 \\
Electoral competition (refers to Table III) & 8.437 & 75.739 & 50.118 & 16.597 \\
Newspaper readership & 0.117 & 0.300 & 0.216 & 0.041 \\
Higher Education & 12.3 & 27.2 & 19.756 & 3.747 \\
Population under 18 & 23 & 34.6 & 26.372 & 2.081 \\
Power of governors & 2.5 & 4.3 & 3.382 & 0.409 \\
Population density & 1.1 & 1076.7 & 172.726 & 238.079 \\
Size of government & 1741 & 8157 & 2568.04 & 959.477 \\
Economic diversity & 24.3 & 93.5 & 70.966 & 15.988 \\
Economic diversity (refers to Table III) & 0.392 & 0.823 & 0.675 & 0.094 \\
Economic development & 17554 & 32632 & 23069.1 & 3227.445 \\
Gross state product & 14.1 & 940.1 & 149.504 & 172.725 \\
\hline
\end{tabular}

Note: Except when otherwise indicated, all provided descriptive statistics refer to the data employed in Table I

\section{REFERENCES}

Adserà, Alícia, Carles Boix and Mark Payne (2003). Are You Being Served? Political Accountability and Quality of Government, The Journal of Law, Economics, \& Organization. 19(2): 445-490.

Artés, Joaquín and Enrique Garcia Vinuela (2007). Campaign spending and office-seeking motivations: an empirical analysis, Public Choice. 133: 41-55.

Ashworth, Scott (2006). Campaign Finance and Voter Welfare with Entrenched Incumbents, American Political Science Review. 100(1): 55-68.

Ansolabehere, Stephen, John M. de Figueiredo and James M. Snyder Jr. (2003). Why is There so Little Money in U.S. Politics, Journal of Economic Perspectives. 17(1): 105-130.

Austen-Smith, David (1987). Interest Groups, Campaign Contributions, and Probabilistic Voting, Public Choice. 54: 123-39.

Baron, David P. (1994). Electoral Competition with Informed and Uninformed Voters, American Political Science Review. 88(1): 33-47.

Baumgartner, Frank R. and Beth L. Leech (1998). Basic Interests: The Importance of Groups in Politics and Political Science. Princeton, NJ: Princeton University Press.

Berry, Jeffrey M. (1997). The Interest Group Society. New York: HarperCollins.

Besley, Timothy J. and Robin Burgess 2002. The political economy of government responsiveness: theory and evidence from India, Quarterly Journal of Economics. 117(4): 1415-1451.

Beyle, Thad (2001). Governors' Power Rating, 2001, in: Hovey, Kendra A. (ed.), CQ's State Fact Finder. Washington, DC: CQ Press: 118-119.

Bibby, John F. and Thomas M. Holbrook (1999). Parties and Elections, in: Gray, Virginia and Russell L. Hanson (eds)., Politics in the American States: A Comparative Analysis. $7^{\text {th }}$ ed. Washington, DC: Congressional Quarterly Press: 66-112.

Bibby, John F. and Thomas M. Holbrook (2004). Parties and Elections, in: Gray, Virginia and Russell L. Hanson (eds)., Politics in the American States: A Comparative Analysis. $8^{\text {th }}$ ed. Washington, DC: Congressional Quarterly Press: 62-99. 
Bischoff, Ivo (2003). Determinants of the increase in the number of interest groups in western democracies: Theoretical considerations and evidence from 21 OECD countries, Public Choice. 114: 197-218.

Brant, Rollin (1990). Assessing proportionality in the proportional odds model for ordinal logistic regression, Biometrics. 46: 1171-1178.

Bruns, Christian and Oliver Himmler (2008). Could you hand me the efficiency section please? Newspaper circulation and local government efficiency in Norway, Munich Personal RePEc Archive Paper No. 12582.

Chatterjee, Samprit, Ali S. Hadi and Bertram Price (2000). Regression Analysis by Example. $3^{\text {rd }}$ ed. New York: John Wiley \& Sons.

Coate, Stephen (2004). Pareto improving campaign finance policy, American Economic Review. 94(3): $628-655$

Crain, Mark and Robert Tollison (1979). The Executive Branch in the Interest Group Theory of Government, Journal of Legal Studies. 8: 855-867.

Dahl, Robert A. (1961). Who Governs? New Haven, Conn.: Yale University Press.

Dahl, Robert A. and Edward R. Tufte (1973). Size and Democracy. Stanford, CT: Stanford University Press.

Deininger, Klaus and Paul Mpuga (2005). Does greater accountability improve the quality of public service delivery? Evidence from Uganda, World Development. 33: 171-191.

Downs, Anthony (1957). An Economic Theory of Democracy. New York: Harper and Row.

Eichenberger, Reiner and Angel Serna (1996). Random Errors, Dirty Information and Politics, Public Choice. 86: 137-156.

Ferguson, Thomas (1983). Party Realignment and American Industrial Structure: The Investment Theory of Parties in Historical Perspective, Research in Political Economy.. 6: 4-120.

Gastil, John (2000). By Popular Demand: Revitalizing Representative Democracy through Deliberative Elections. Berkeley, CA: University of California Press.

Goodliffe, Jay (2001). The effect of war chests on challenger entry in U.S. house elections, American Journal of Political Science. 45(4): 830-844.

Gray, Virginia and David Lowery (1996). The Population Ecology of Interest Representation: Lobbying Communities in the American States. Ann Arbor: University of Michigan Press.

Gray, Virginia and David Lowery (2001). The Institutionalization of State Communities of Organized Interests, Political Research Quarterly. 54(2): 265-284.

Gray, Virginia, David Lowery and M. Fellowes (2005). Organized interests and political extortion: A test of the Fetcher Bill hypothesis, Political Science Quarterly. 86(2): 368-385.

Grier, Kevin B., Michael C. Munger and Brian E. Roberts (1994). The Determinants of Industry Political Activity, 1978-1986, American Political Science Review. 88: 911-926.

Grier, Kevin B. and Michael C. Munger (1991). Committee Assignments, Constituent Preferences, and Campaign Contributions, Economic Inquiry. 24: 24-43.

Grossman, Gene M. and Elhanan Helpman (1994). Protection for sale, American Economic Review. 84: 833-850.

Grossman, Gene M. and Elhanan Helpman (1996). Electoral competition and special interest politics, Review of Economic Studies. 63: 265-286.

Heinz, John P., Edward O. Laumann, Robert L. Nelson and Robert H. Salisbury (1993). The Hollow Core: Private Interests in National Policymaking. Cambridge, MA: Harvard University Press.

Hillman, Arye and Heinrich W. Ursprung (1988). Domestic Politics, Foreign Interests, and International Trade Policy, American Economic Review. 78(4): 729-745.

Hogan, Robert E. (2001). Campaign War Chests and Challenger Emergence in State Legislative Elections, Political Research Quarterly. 54(4): 815-830.

Holbrook, Thomas M. and Emily van Dunk (1993). Electoral Competition in the American States, American Political Science Review. 87(4): 955-962. 
Kennelly, Brendan and Peter Murrell (1991). Industry characteristics and interest group formation. An empirical study, Public Choice. 70: 21-40.

Larcinese, Valentino (2009). Information Acquisition, Ideology and Turnout: Theory and Evidence from Britain, Journal of Theoretical Politics. 21(2): 237-276.

Leech, Beth L., Frank R. Baumgartner, Timothy La Pira and Nicholas A. Semanko (2005). Drawing Lobbyists to Washington: Government Activity and the Demand for Advocacy, Political Research Quarterly. 58(1): 19-30.

Levitt, Steven D. (1994). Using repeat challengers to estimate the effects of campaign spending on election outcomes in the U.S. house, Journal of Political Economy. 102: 777-798.

Lipset, Seymour M. (1981). Political Man: The Social Basis of Politics. MD: John Hopkins University Press.

Lowery, David and Virginia Gray (1997). How some rules just don't matter: The regulation of lobbyists, Public Choice. 91: 139-147.

Lowery, David and Virginia Gray (2004). Bias in the heavily chorus. Interests in society and before government, Journal of Theoretical Politics. 16(1): 5-30.

Moe, Terry M. (1980). A Calculus of Group Membership, American Journal of Political Science. 24(4): 593-632.

Morehouse, Sarah M. (1981). State Politics, Parties and Policy. New York: Holt, Rinehart and Winston.

Oberholzer-Gee, Felix and Joel Waldfogel (2006). Strength in Numbers: Group Size and Political Mobilization, Journal of Law and Economics. 48(1): 73-91.

Olson, Mancur (1965). The Logic of Collective Action. Cambridge: Harvard University Press.

Potters, Jan, Randolph Sloof and Frans van Winden (1997). Campaign Expenditures, Contributions, and Direct Endorsements: The Strategic Use of Information and Money to Influence Voter Behavior, European Journal of Political Economy. 13(1): 1-31.

Prat, Andrea (2002). Campaign Spending with Office-Seeking Politicians, Rational Voters and Multiple Lobbies, Journal of Economic Theory. 103: 162-189.

Putnam, Robert (2000). Bowling Alone: The Collapse and Revival of American Community. New York: Simon and Schuster.

Ranney, Austin (1976). Parties in State Politics, in: Herbert Jacob and Kenneth Vines (eds.), Politics in the American States: A Comparative Analysis. Boston: Little Brown.

Roscoe, Douglas and Shannon Jenkins (2005). A meta-analysis of campaign contributions' impact on roll call voting, Social Science Quarterly. 86(1): 52-68.

Rothenberg, Lawrence S. (1988). Organizational Maintenance and the Retention Decision in Groups, American Political Science Review. 82(4): 1129-1152.

Salisbury, Robert H. (1969). An Exchange Theory of Interest Groups, Midwest Journal of Political Science. 13: 1-32.

Salisbury, Robert H. (1975). Interest Groups, in: Greenstein, Fred I. and Nelson W. Polsby (eds.), Nongovernmental Politics. Reading, MA: Addison-Wesley.

Shughart, William F., Robert D. Tollison and Zhipeng Yan (2003). Rent Seeking into the Income Distribution, Kyklos. 56(4): 441-456.

Smith, Mark A. (1998). Legislative competition data file for the period 1973-1991. Department of Political Science, University of Washington.

Stigler, George A. (1976). The Sizes of Legislatures, Journal of Legal Studies. 5: 17-34.

Stratmann, Thomas (2005). Some talk: Money in politics. A (partial) review of the literature, Public Choice. 124: 135-156.

Stratmann, Thomas and Francisco J. Aparicio-Castillo (2006). Competition policy for elections: Do campaign contribution limits Matter? Public Choice. 127: 177-206.

Strömberg, David (2001). Mass media and public policy, European Economic Review. 45: 652-663. Strömberg, David (2004a). Radio's Impact on Public Spending, The Quarterly Journal of Economics. 119(1): 189-221. 
Strömberg, David (2004b). Mass Media Competition, Political Competition, and Public Policy, Review of Economic Studies. 71: 265-284.

Thomas, Clive S. and Ronald J. Hrebenar (1999). Interest Group Power in the Fifty States: Trends since the Late 1970s, Comparative State Politics. 20: 3-17.

Thomas, Clive S. and Ronald J. Hrebenar (2004). Interest Groups in the States, in: Gray, Virginia and Russell L. Hanson (eds.), Politics in the American States: A Comparative Analysis. $8^{\text {th }}$ ed. Washington, DC: Congressional Quarterly Press: 100-28.

Tóka, Gábor (2008). Citizen information, election outcomes and good governance, Electoral Studies. 27: $31-44$.

Truman, David B. (1951). The Governmental Process: Political Interests and Public Opinion. New York: Alfred A. Knopf.

Van Dunk, Emily and Ronald E. Weber (1997). Constituency-level competition in the US states, 1968-1988: A pooled analysis, Legislative Studies Quarterly. 22: 141-159.

Wagner, John E. and Steven C. Deller (1998). Measuring the Effects of Economic Diversity on Growth and Stability, Land Economics. 74(4): 541-556.

White, Halbert (1980). A Heteroscedasticity-Consistent Covariance Matrix Estimator and a Direct Test for Heteroscedasticity, Econometrica. 48: 817-838.

Windmeijer, Frank A.G. (1995). Goodness-of-fit measures in binary choice models, Econometric Reviews. 14(1): 101-116.

Zeller, Belle (1954). American State Legislature. $2^{\text {nd }}$ ed. New York: Crowell.

\section{SUMMARY}

This paper analyses how certain electoral settings affect the activity of special interest groups within US state politics. The main result of cross-sectional regression analyses suggests that informed and educated voters prevent political parties from catering to special interests, diminishing the number of lobby registrations, the total amount of campaign contributions as well as groups' overall influence. Electoral competition is believed to exert a curvilinear effect on groups' importance within the political decision making process of each state. Another finding indicates that, in a situation of high electoral competition, voters' level of information plays a pivotal role in determining interest groups' activities. Parties seem to increasingly value median voter's concerns whenever the electorate is informed and political races are expected to beclose. An environment of competitive elections and uninformed voters, in contrast, furthers interest groups' activity and strengthens their position within the political arena. This is explained by the rationale that, under such circumstances, politicians increasingly exchange narrowly targeted policies for campaign contributions in order to buy the votes of impressionable citizens. 